\title{
Mechanism of the Inhibition of Germination of Bacterial Spores by $\gamma$-Irradiation in the Presence of Iodoacetamide and Iodate
}

\author{
By G. W. GOULD \\ Unilever Research Laboratory, Colworth House, Sharnbrook, Bedford
}

(Accepted for publication 22 October 1970)

\begin{abstract}
SUMMARY
Whereas $\gamma$-radiation alone either did not affect or stimulated spore germination, spores which had been irradiated in the presence of iodoacetamide (IAM) or potassium iodate were inhibited from germinating in germinants like L-alanine, inosine or yeast glucose broth. Activity of a lytic enzyme which may be involved in germination was mostly lost in spores irradiated in IAM, and a phosphomonoesterase was about $60 \%$ inhibited. Spore alanine racemase was partly inactivated by $\gamma$-radiation alone but, with spore protease, survived irradiation in IAM without much further loss of activity. Although spores made non-germinable by $\gamma$-radiation plus IAM were nonviable as measured by colony counts, viability could be partly restored by chemical treatments known to by-pass the normal germination reactions. It was concluded that spores were inactivated by $\gamma$-radiation in the presence of the potentiators through inactivation of enzyme(s) essential in the degradative reactions of germination. The enzyme inactivation was caused by iodinecontaining free radicals rather than directly by the $\gamma$-radiation.
\end{abstract}

\section{INTRODUCTION}

Growth from bacterial spores occurs in the following sequence of stages: activation, germination, outgrowth, vegetative cell growth and multiplication (Keynan \& Halvorson, 1965). The term 'activation' describes any treatment (commonly heat; Curran \& Evans, 1945) which causes the spores to germinate more rapidly or more completely than if untreated. Germination refers to a number of more or less concurrent changes which rapidly occur when activated spores are incubated in solutions of the correct chemicals (germinants) at a suitable $\mathrm{pH}$ value, temperature, etc. Germinating spores change from bright to dark, as seen with a phase-contrast microscope, and swell; the extinction of a spore suspension decreases during germination, and the spores excrete materials including calcium, dipicclinic acid and peptidoglycan components; metabolic activities become detectable in germinating spores, and their heat resistance decreases abruptly. Outgrowth describes emergence of the new vegetative cell from the spore coat and its elongation prior to the first cell division.

Activation and germination can occur under conditions which are unsuitable for outgrowth and vegetative cell growth. For instance, spores of many organisms will germinate, but not outgrow, in solutions containing single germinants like L-alanine or inosine only or containing inhibitors of growth (Gould, I969). Even non-viable spores which are unable to give rise to dividing vegetative forms or colonies may still be able to germinate. For instance, about $99 \%$ of Bacillus cereus spores in a suspension 
were inactivated by exposure to $0.54 \mathrm{Mrad}$ of $\gamma$-radiation as measured by colony counts, yet the radiation-inactivated spores actually germinated faster than unirradiated controls when incubated in solutions of germinant compounds (Gould \& Ordal, 1967).

During an investigation of such radiation-inactivated spores we exposed spores of Bacillus cereus to $\gamma$-radiation in the presence of iodoacetamide (IAM), iodate and other halogen compounds (Gould, 1970). Radiation acted synergistically in inactivating spores as measured by colony counts and, surprisingly, spores irradiated in the presence of IAM and iodate lost the ability to germinate. Inhibition of germination was in such contrast to the stimulation of germination which frequently resulted from $\gamma$-irradiation alone that we studied further the combined effects of the potentiators and radiation on spores. It was hoped that this study might lead to a better understanding of spore germination, and also help to explain the strong potentiation by IAM, iodate and related compounds of the lethal action of ionizing radiation for some radiation-resistant vegetative bacteria.

\section{METHODS}

Spores. Bacillus cereus strain PX was principally used. Other organisms used were B. coagulans NCTC 399I, B. polymyxa strain MI, B. subtilis (globigii) and B. cereus strain T. Spores were prepared as described previously (Gould, 1970).

Germination and outgrowth studies. Germination was measured by following the decrease in extinction of spore suspensions in a Hilger 'Biochem' absorptiometer. Initial extinction at $580 \mathrm{~nm}$. was always about 0.3 and corresponded to about $38 \mu \mathrm{g}$. dry weight or $2.2 \times 10^{7}$ organisms $/ \mathrm{ml}$. The suspensions were incubated at $30^{\circ}$ in sodium phosphate buffer $(80 \mathrm{mM}, \mathrm{pH} 8.0$ ) containing L-alanine (IO mM), inosine (I00 $\mu \mathrm{M}$ ) or $n$-dodecylamine (laurylamine; I/5 saturated solution) as germinants (Koch-Light Laboratories Ltd, Colnbrook, Buckinghamshire) or in calcium dipicolinate (30 mM $\mathrm{CaCl}_{2}$ plus $30 \mathrm{~mm}$ sodium dipicolinate made from the acid (Aldrich Chemical Corp., Milwaukee, Wisconsin, U.S.A.)) in tris $\mathrm{HCl}$ buffer $(80 \mathrm{mM}, \mathrm{pH} 8 \cdot 0$ ). Spores were sometimes activated by heating at $70^{\circ}$ for $30 \mathrm{~min}$. (see Results) immediately before germination. Germination indicated by a fall in extinction was confirmed by examining samples with a phase-contrast microscope. Outgrowth was measured by incubating spores in yeast glucose broth at $30^{\circ}$ and measuring the extinction at intervals. After the initial fall in extinction due to germination, outgrowth and synthesis of new cell material caused a rise in extinction value.

Radiation. Spore suspensions in I ml. amounts in sealed glass ampoules or in $50 \mathrm{ml}$. amounts in closed plastic bottles were irradiated with $\gamma$-rays from a Co6o source at a dose rate of about $0.8 \mathrm{Mrad} / \mathrm{h}$. under essentially anoxic conditions. Temperature was not controlled during irradiation but did not exceed $30^{\circ}$ in any experiment. The spores were suspended in distilled water during irradiation or in aqueous solutions as indicated in the Results. Iodoacetamide and potassium iodate were purchased from British Drug Houses Ltd, Poole, Dorset.

Following irradiation, samples were held on ice and used within $4 \mathrm{~h}$. of the termination of radiation. Irradiated spores intended for germination, outgrowth and enzyme studies were washed by centrifuging from water three times before use to remove any chemicals or soluble radiation products. 
Viable counts were performed as described before (Gould, 1970).

Enzyme assays. Alanine racemase in unbroken spores was detected by incubating spores $(5 \mathrm{mg}$. equiv. dry $\mathrm{wt} / \mathrm{ml}$.) in sodium phosphate buffer $(80 \mathrm{mM}, \mathrm{pH} 8 \cdot 0)$ plus L-alanine $(100 \mathrm{mM})$ at $30^{\circ}$; samples were taken at intervals, cooled to about $4^{\circ}$, and spores quickly removed by centrifuging; the amount of D-alanine in the supernatants (formed by racemization) was then estimated by measuring oxygen uptake of samples incubated at $35^{\circ}$ in a Warburg apparatus with D-amino acid oxidase (ex. hog kidney, British Drug Houses Ltd) (Yoshimoto, 1958). The reaction mixtures consisted of sample ( $0.5 \mathrm{ml}$.) oxidase ( $15 \mathrm{mg}$.), sodium phosphate ( $\mathrm{pH} 8.0 ; 40 \mu$ moles) in a total volume of $3 \mathrm{ml}$. (Fey, Gould \& Hitchins, 1964). L- or D-Alanine (15 $\mu$ moles) were used as controls.

Spore lytic enzyme was prepared from the supernatant fluid of suspensions of spores (equiv. to $20 \mathrm{mg}$. dry wt $/ \mathrm{ml}$.) which had been disrupted by shaking with glass beads as described by Gould, Hitchins \& King (1966). The enzyme was assayed by its ability to cause a decrease in the extinction of suspensions of spores which had been sensitized by incubation in thioglycollic (mercaptoacetic) acid $(25 \%, \mathrm{v} / \mathrm{v})$ plus urea $(6 \mathrm{M})$ at $70^{\circ}$ for $30 \mathrm{~min}$. (Gould et al. 1966). The enzyme reaction was carried out in sodium phosphate buffer $(100 \mathrm{mM}, \mathrm{pH} 8.0)$ at $37^{\circ}$; the initial extinction read at $580 \mathrm{~nm}$. was always about 0.3. Dithiothreitol (O.I mM; Calbiochem Ltd, Basingstoke, Hampshire; Hsu, Wasson \& Porter, 1965) was included in all solutions containing spore lytic enzyme to maintain the enzyme in its active reduced state in place of the sodium thioglycollate used previously (Gould \& Hitchins, 1965).

Protease was measured by incubating spore homogenates ( $\mathrm{I} \mathrm{ml}$.) with Azocoll ( 0. I g.; Calbiochem Ltd) at $37^{\circ}$. Liberation of soluble dye by protease action was measured by following changes in extinction of the supernatants at $470 \mathrm{~nm}$.

Phosphomonoesterase was detected by incubating spore homogenates ( $\mathrm{I} \mathrm{ml}$.) with phenolphthalein diphosphate (200 $\mu \mathrm{g}$., Koch-Light Laboratories Ltd) and sodium acetate $(200 \mu$ moles, $\mathrm{pH} 5.4)$ in a total volume of $3 \mathrm{ml}$. at $37^{\circ}$. At intervals an equal volume of $\mathrm{NaOH}$ solution $(\mathrm{I} \% \mathrm{w} / \mathrm{v})$ was added to samples of the supernatant to develop the colour of released phenolphthalein, which was measured by extinction at $520 \mathrm{~nm}$.

\section{RESULTS}

Growth after different germinant treatments of spores $\gamma$-irradiated in the presence of iodoacetamide or iodate

Irradiated spores of Bacillus cereus $\mathbf{P X}$ germinated more rapidly than unirradiated spores (Gould \& Ordal, 1967) but, in contrast, spores irradiated with IAM or with potassium iodate were inhibited from subsequent germination. Fig. I shows the extent of this inhibition with IAM when the germinant was inosine and the spores had been heat-activated to mask most of the radiation activation. Contact with IAM in the absence of radiation slightly depressed the rate of spore germination in inosine even though the spores were washed free of exogenous IAM (Fig. I). Contact with IAM had little effect on subsequent germinability of spores in L-alanine, but spores irradiated in IAM did not germinate (Fig. 2). That inhibition was not due to residual traces of IAM was shown by the fact that germination of unirradiated and irradiated spores was hardly inhibited by even Io mM IAM.

Calcium dipicolinate, which will germinate some bacterial spores (Riemann \& Ordal, 
I96I), germinated heat-activated Bacillus cereus PX spores at the same rate whethe, or not they had been irradiated (Fig. 3). Spores which had been exposed to IAM however, with or without radiation, germinated faster (Fig. 3). This interesting effect of IAM was observed several times, and cannot be explained. The so-called 'chemical germinant' $n$-dodecylamine (laurylamine; Rode \& Foster, I960) germinated $\gamma$-irradiated spores more rapidly than control spores and thus confirmed the radiation

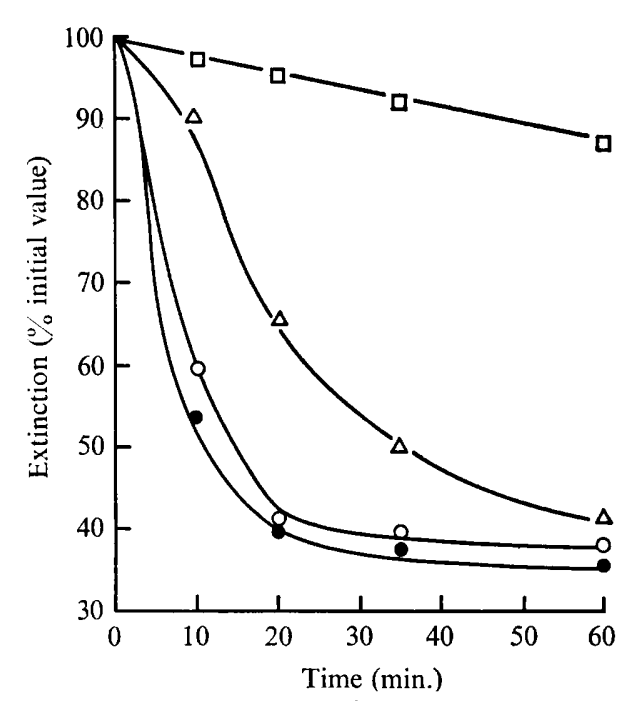

Fig. I

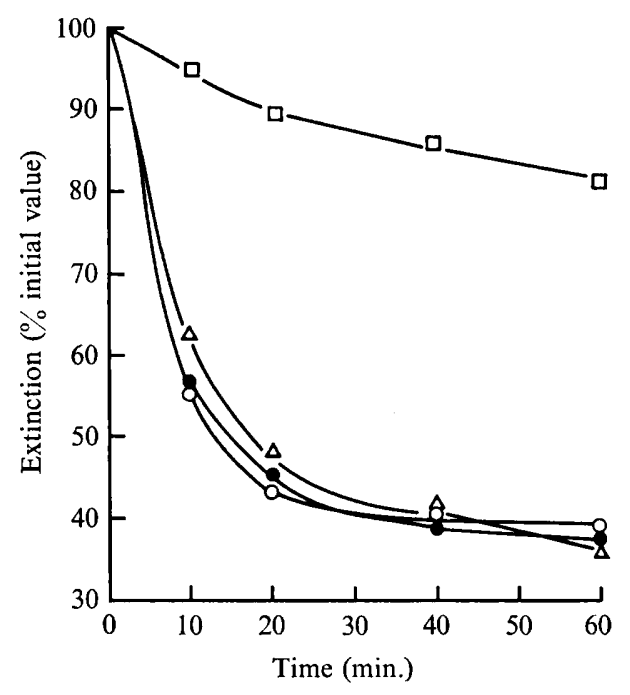

Fig. 2

Fig. 1. Change in extinction during inosine-initiated germination of spores of Bacillus cereus $\gamma$-irradiated in the presence or absence of iodoacetamide. The $\gamma$-radiation dose was $0.2 \mathrm{Mrad}$, the spore concentration during irradiation was about $1.5 \times 10^{9} \mathrm{ml}$. in water, and iodoacetamide was used at $\mathrm{I} \mathrm{mM}$. Washed spores were heat-activated and then incubated at $30^{\circ}$ in inosine $(100 \mu \mathrm{M})$ to initiate germination as described in Methods. $\bigcirc$, Control spores; , irradiated spores; $\triangle$, IAM-treated spores; $\square$, spores irradiated in the presence of IAM.

Fig. 2. L-Alanine-initiated germination of spores of Bacillus cereus $\gamma$-irradiated in the presence or absence of iodoacetamide. Experimental details and symbols as in Fig. I, except that $\mathrm{L}$-alanine (Io $\mathrm{mM}$ ) was used to initiate germination in place of inosine.

activation reported earlier (Gould \& Ordal, 1967). Radiation activation was not masked by heating the spores when $n$-dodecylamine was the germinant since heat does not activate spores for germination in $n$-dodecylamine (Rode \& Foster, 196I). Exposure of spores to IAM slowed their subsequent germination in $n$-dodecylamine, and spores $\gamma$-irradiated in IAM germinated still more slowly (Fig. 4).

\section{Outgrowth from $\gamma$-irradiated spores}

Fig. 5 shows the course of germination and early outgrowth of Bacillus cereus $\mathbf{P X}$ spores in yeast glucose broth. It can be seen that the $\gamma$-irradiated spores, which were $>90 \%$ viable by colony count, germinated and commenced outgrowth at almost the same rate as control spores. Contact with IAM allowed spores to germinate and outgrow, though more slowly than controls. In contrast, spores which had been irradiated in the presence of IAM hardly germinated at all, and the rise in extinction which characterizes outgrowth did not occur. Qualitatively similar results were obtained when potassium iodate was used in place of IAM. 


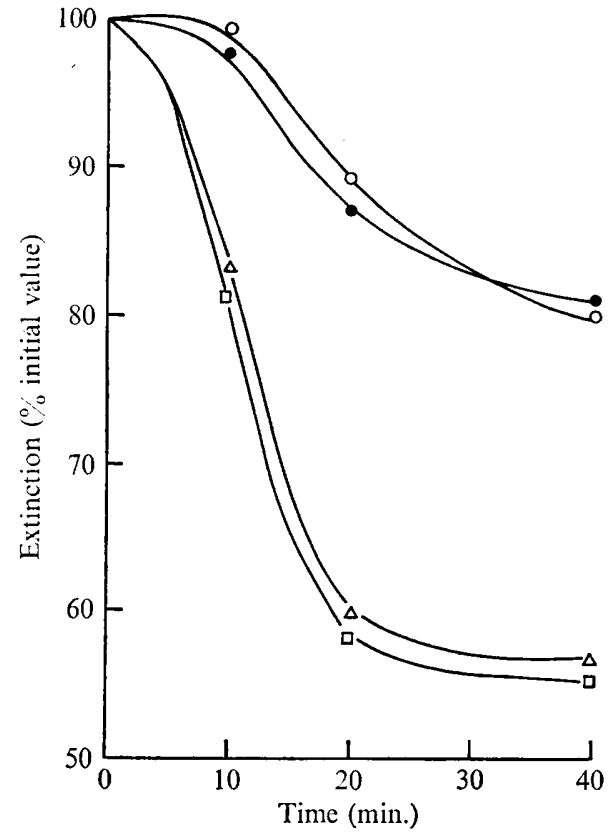

Fig. 3

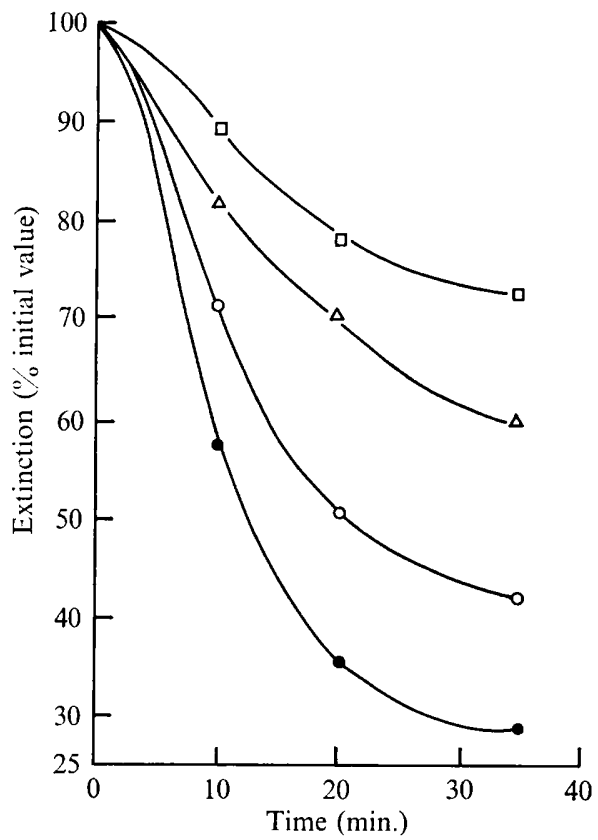

Fig. 4

Fig. 3. Calcium dipicolinate-initiated germination of spores of Bacillus cereus $\gamma$-irradiated in the presence or absence of iodoacetamide. Experimental conditions as in Fig. I, except that calcium dipicolinate (10 mM) was used to initiate germination (see Methods) in place of inosine. $O$, Control spores; $\boldsymbol{O}$, irradiated spores; $\triangle$, IAM-treated spores; $\square$, spores irradiated in the presence of IAM.

Fig. 4. $n$-Dodecylamine-initiated germination of spores of Bacillus cereus $\gamma$-irradiated in the presence or absence of iodoacetamide. Experimental details and symbols as in Fig. I except that $n$-dodecylamine ( $\mathrm{I} / 5$ saturated solution) was used to initiate germination in place of inosine.

\section{Reversal of inhibition of germination}

An unsuccessful attempt was made to reverse the inhibition of germination by incubating in sodium thioglycollate ( $\mathrm{IO}$ and $\mathrm{I} 00 \mathrm{mM}, \mathrm{pH} 8.0,37^{\circ}$ for $\mathrm{I} \mathrm{h}$.) spores $\gamma$-irradiated in IAM. In a further attempt to by-pass the block in germination, the variously treated spores were incubated with thioglycollic acid and then with lysozyme, a procedure which is known to cause germination-like changes in spores (Gould \& Hitchins, 1963). The results (Table I) showed that although this treatment caused about $75 \%$ loss of viability, it also caused some recovery of viability of the spores $\gamma$-irradiated in IAM; full recovery could not be obtained.

\section{Enzymic activities of spores $\gamma$-irradiated in iodoacetamide}

The reaction sequences involved when spores germinate in simple germinants like L-alanine or inosine are not certainly known, so four enzyme systems which are thought to play some part in germination were arbitrarily chosen and assayed in the variously treated spores. Table 2 shows that the effect of $0.6 \mathrm{Mrad} \gamma$-radiation on the spore enzymes was small, except for the lytic enzyme, which was barely detectable in extracts from spores irradiated in IAM (more than $95 \%$ inhibition was also found 
with enzyme from spores irradiated in IAM at the lower dose of $0.2 \mathrm{Mrad}$ ), and the phosphomonoesterase, which was about $60 \%$ inactivated by irradiation of spores in IAM. The level of alanine racemase was depressed by radiation whether or not IAM was present and protease activity was relatively unaffected by any of the treatments.

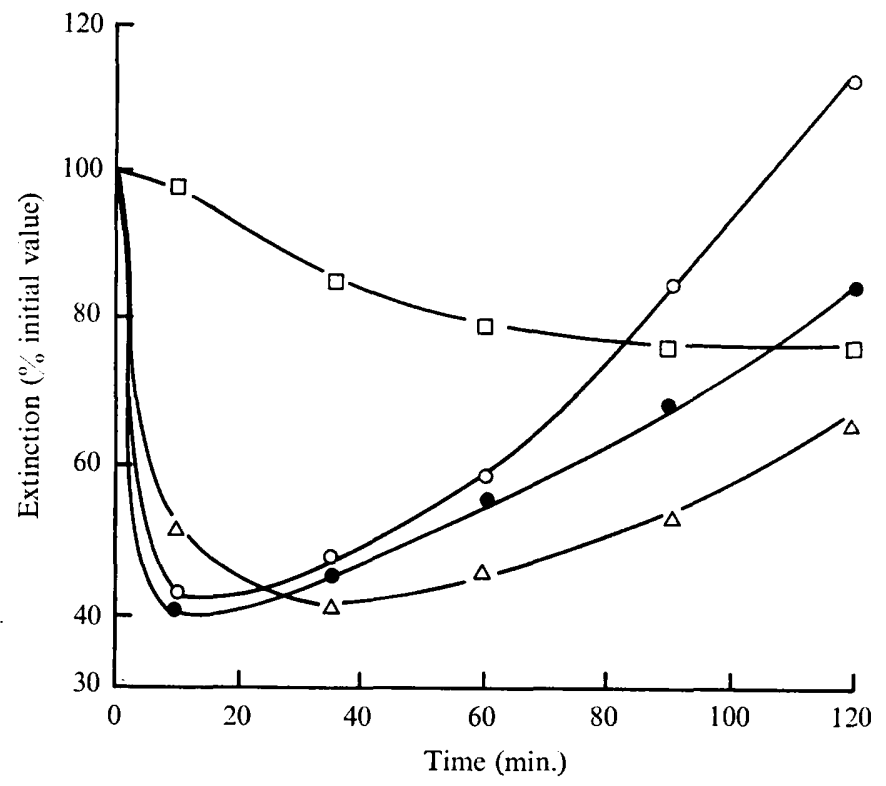

Fig. 5. Germination and outgrowth of spores of Bacillus cereus $\gamma$-irradiated in the presence or absence of iodoacetamide. Spores were irradiated \pm IAM as detailed in Fig. I, then washed, heat-activated and incubated at $30^{\circ}$ in yeast glucose broth. The figure shows the fall in extinction due to germination and the rise in extinction due to outgrowth. $\bigcirc$, Control spores; $\bullet$, irradiated spores; $\triangle$, IAM-treated spores; $\square$, spores irradiated in the presence of IAM ( $\square$ ).

\section{DISCUSSION}

Potentiation by iodoacetamide and potassium iodate of the lethal action of ionizing radiation is particularly obvious with radiation-resistant organisms like Micrococcus radiodurans (Dean \& Alexander, 1962) and Escherichia coli $\mathrm{B} / \mathrm{r}$ (Kada, 1969). Action of halogen-containing potentiators may depend on production by radiolysis of free radicals which are toxic to bacteria, and which are short-lived in the presence of most organic materials (Dewey \& Michael, 1965). The lethal free radical(s) may inactivate vegetative bacteria by reaction with some protein component of the plasma membrane, possibly a protein necessary for repair of radiation-damaged DNA (Shenoy, Singh \& Gopal-Ayengar, 1968); membrane damage has been demonstrated in yeast X-irradiated in the presence of IAM (Myers \& Karazin, 1968). Kada, Noguti \& Namiki (1970) showed that iodide did not enhance the radiosensitivity of transforming deoxyribonucleic acid from Bacillus subtilis in vitro. The exact mechanism of action of these potentiators is, however, not yet known.

Study of the effect of halogen compounds as potentiators of the radiation-inactivation of spores (Gould, 1970) suggested that the same radiation-induced free radicals that inactivated some vegetative bacteria also inactivated spores. Nevertheless, the results of the present work strongly suggest that the lethal action of the free radicals, 
at least on spores, is quite unrelated to the usual radiation inactivation mechanism and does not primarily involve damage either to deoxyribonucleic acid (DNA) or to DNA repair systems. The mechanisms of death of Bacillus cereus spores caused by $\gamma$-radiation alone and by $\gamma$-radiation plus IAM or iodate are very obviously different. $\gamma$-Radiation alone did not inhibit germination, but arrested the stage of late outgrowth from spores. Inhibition of outgrowth is compatible with death due to irreparable damage to DNA, for DNA synthesis and replication does not commence until this stage (Woese \& Forro, I960). In contrast, spores killed by $\gamma$-radiation in the presence

\section{Table I. Partial reversal by lysozyme of the inhibition of germination of Bacillus cereus spores caused by $\gamma$-radiation +iodoacetamide}

Spores $\left(\mathrm{I} .5 \times 10^{9} / \mathrm{ml}\right.$.) were irradiated with $0.6 \mathrm{Mrad}$ in the presence or absence of IAM $(10 \mathrm{mM})$, then washed and treated with thioglycollic acid $(10 \%, \mathrm{w} / \mathrm{v})$ in urea $(6 \mathrm{M})$ at $37^{\circ}$ for $30 \mathrm{~min}$., followed by lysozyme (100 $\mu \mathrm{g} . / \mathrm{ml}$.) in sodium phosphate buffer (100 $\mathrm{mM}, \mathrm{pH} 7^{\circ} 0$ ) at $37^{\circ}$ for $30 \mathrm{~min}$. Samples were then rapidly diluted into poured plates of yeast glucose agar for estimation of viability by colony count. For controls, samples were treated similarly except that lysozyme was omitted.

\section{Sample}

Unirradiated spores

Irradiated spores

Spores irradiated in IAM

\begin{tabular}{|c|c|}
\hline $\begin{array}{c}\text { Control } \\
\text { treatment }\end{array}$ & $\begin{array}{l}\text { Lysozyme } \\
\text { treatment }\end{array}$ \\
\hline $\begin{array}{l}100 \\
0.36 \\
0.0071\end{array}$ & $\begin{array}{l}24.2 \\
0.096 \\
0.019\end{array}$ \\
\hline
\end{tabular}

Table 2. Activity of enzymes from spores of Bacillus cereus $\gamma$-irradiated in the presence of iodoacetamide

Measurement of enzyme activities are described in Methods. Spores ( $1.5 \times 10^{\circ} / \mathrm{ml}$.) were irradiated with $0.6 \mathrm{Mrad}$ in the presence or absence of IAM (IO mM). For controls, spores were held at ambient temperature \pm IAM for an equivalent time.

Activity (\% of activity in untreated control spores)

\section{Enzyme}

Protease

Alanine racemase

Phosphomonoesterase

Lytic enzyme

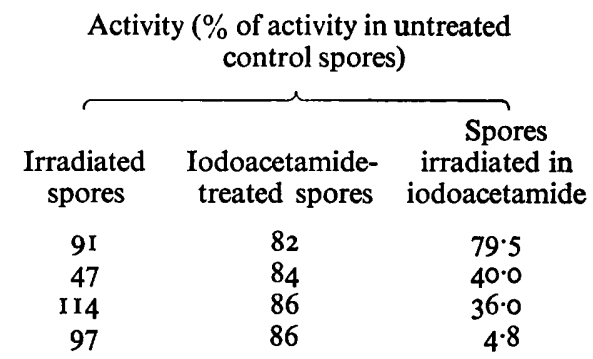

of the potentiators failed to germinate in germinants like L-alanine and inosine which probaby act via a sequence of enzyme reactions. This stage of germination precedes the synthetic reactions of outgrowth and is essentially a degradative process.

Since spores which had been irradiated plus IAM could still be attacked by lysozyme, any great change in the peptidoglycan component of spores caused by $\gamma$-radiation plus IAM seems unlikely. Of the four enzymes studied which may be involved in germination, only a lytic enzyme, first described by Strange \& Dark (1957), and a phosphomonoesterase were strongly inhibited specifically by radiation plus IAM. The lytic enzyme can cause germination of suitably sensitized spores (Gould \& Hitchins, 1965) and it may well operate during normal spore germination. 
Iodination of bacteria by chemically reactive $\mathrm{I}$ formed from $\mathrm{I}^{-}$plus peroxidase in a $\mathrm{H}_{2} \mathrm{O}_{2}$-generating system has been shown to be a highly bactericidal mechanism (Kebanoff, 1967) which probably involves reaction of I with tyrosyl residues in enzyme proteins. It is known that the spore lytic enzyme can be inhibited by iodine (Gould et al. 1966). The potentiation of lethality of $\gamma$-radiation for spores by IAM, and probably also by iodate and other iodine- and bromine-containing potentiators, was therefore probably due to inactivation of this enzyme, and perhaps others, within spores by the radiation induced halogen radical. Inactivation in vitro of other enzymes by $\mathrm{X}$-irradiation in the presence of potentiators (iodide and 3-iodopropionic acid) has been described (Gorin, Quintiliani \& Airee, 1967). If $\gamma$-radiation plus IAM impairs only the germination mechanism in spores, it should be possible to restore viability (i.e. ability to form colonies) by by-passing the usual germination mechanism. The attempt to do this using lysozyme to germinate the spores was only partially successful, suggesting that enzymes involved in outgrowth or vegetative cell growth, in addition to those important in germination, might be inactivated by $\gamma$-radiation plus IAM. Calcium dipicolinate also caused spores irradiated in the presence of IAM to germinate and therefore evidently by-passed the damaged germination mechanism. It is not, however, known whether the spores germinated in this way were viable.

The corresponding sites of damage in radiation-resistant vegetative bacteria are not known, but it would be of interest to determine whether (auto-) lytic enzymes in these organisms, which one would expect to act near the cell surface and which may play a role in cell wall growth (Shockman, 1965), are inhibited by ionizing radiation when in the presence of halogen-containing potentiators.

The author is grateful to Dr T. A. Roberts for radiation facilities, to Dr B. A. Bridges and Dr P. Alexander for advice and discussion, and to Mr A. K. Jackson and Miss Caroline V. Martindale for efficient technical assistance.

\section{REFERENCES}

Curran, H. R. \& Evans, F. R. (1945). Heat activation inducing germination in the spores of thermotolerant and thermophilic aerobic bacteria. Journal of Bacteriology 49, 335-346.

Dean, C. J. \& AleXander, P. (1962). Sensitization of radioresistant bacteria to X-rays by iodoacetamide. Nature, London I96, I324-I 326.

Dewey, D. L. \& Michael, B. D. (1965). The mechanism of radiosensitization by iodoacetamide. Biochemical and Biophysical Research Communications 2r, 392-396.

Fey, G., Gould, G. W. \& HrTchins, A. D. (I964). Identification of D-alanine as the autoinhibitor of germination of Bacillus globigii spores. Journal of General Microbiology 35, 229-236.

Gorin, G., Quintiliani, M. \& AIREE, S. K. (1967). The inactivation of alcohol dehydrogenase by $\mathrm{X}$-rays and the dose-modifying effect of some added substances. Radiation Research $32,67 \mathrm{I}-$ 684 .

Gould, G. W. (1964). Effect of food preservatives on the growth of bacteria from spores. In Microbial Inhibitors in Food, pp. 17-24. Edited by N. Molin. Stockholm: Almquist \& Wiksel.

Gould, G. W. (1969). Germination. In The Bacterial Spore, pp. 397-444. Edited by G. W. Gould \& A. Hurst. London: Academic Press.

Gould, G. W. (1970). Potentiation by halogen compounds of the lethal action of $\gamma$-radiation on spores of Bacillus cereus. Journal of General Microbiology 64, 289-30I.

Gould, G. W. \& Hitchins, A. D. (1963). Sensitization of bacterial spores to lysozyme and to hydrogen peroxide with agents which rupture disulphide bonds. Journal of General Microbiology 33, 413-423. 
Gould, G. W. \& Hitchins, A. D. (1965). Germination of spores with Strange \& Dark's spore lytic enzyme. In Spores III, pp. 213-221. Edited by L. L. Campbell \& H. O. Halvorson. Ann Arbor, Michigan: American Society for Microbiology.

Gould, G. W., Hitchins, A. D. \& KING, W. L. (1966). Function and location of a germination enzyme in spores of Bacillus cereus. Journal of General Microbiology 44, 293-302.

Gould, G. W. \& ORDAL, Z. J. (1967). Activation of spores of Bacillus cereus by $\gamma$-radiation. Journal of General Microbiology 50, 77-84.

Hsu, R. Y., Wasson, G. \& Porter, J. W. (1965). Purification and properties of the fatty acid synthetase of pigeon liver. Journal of Biological Chemistry 240, 3736-3748.

KADA, T. (I969). Radiosensitization by potassium iodate and related compounds. International Journal of Radiation Biology 15, 27I-274.

KADA, T., NoGUTI, T. \& NAMIKI, M. (I970). Radiosensitization with iodine compounds. I. Examination of damage in deoxyribonucleic acid with Bacillus subtilis transformation system by irradiation in the presence of potassium iodide. International Journal of Radiation Biology 17, 407-418.

KEBANOFF, S. J. (1967). Iodination of bacteria: a bactericidal mechanism. Journal of Experimental Medicine 126, 1063-1072.

Keynan, A. \& Halvorson, H. (1965). Transformation of a dormant spore into a vegetative cell. In Spores III, pp. I74-I 79. Edited by L. L. Campbell \& H. O. Halvorson. Ann Arbor, Michigan: American Society for Microbiology.

Myers, D. K. \& KARAZIN, T. (1968). Comparison of the effects of radiation on the cell membrane and on the reproductive survival of yeast. Radiation Research 35, 6I2-62I.

RiemANN, H. \& ORDAL, Z. J. (I96I). Germination of bacterial endospores with calcium and dipicolinic acid. Science, New York 133, 1703-1704.

RODE, L. J. \& FOSTER, J. W. (196I). Germination of bacterial spores with alkyl primary amines. Journal of Bacteriology 8r, 768-779.

Shenoy, M. A., Singh, B. B. \& Gopal-Ayengar, A. R. (1968). Iodine incorporated in cell constituents during sensitization to radiation by iodoacetic acid. Science, New York 160, 999.

SHockmaN, G. D. (1965). Symposium on the fine structure and replication of bacteria and their parts. IV. Unbalanced cell-wall synthesis: autolysis and cell-wall thickening. Bacteriological Reviews 29, 345-358.

Strange, R. E. \& Dark, F. A. (1957). A cell-wall lytic enzyme associated with spores of Bacillus species. Journal of General Microbiology 16, 236-249.

Woese, C. R. \& Forro, J. R. (1960). Correlations between ribonucleic acid and deoxyribonucleic acid metabolism during spore germination. Journal of Bacteriology 80, 8I I-8 I 7 .

Yоsнiмото, S. (1958). The action of D-amino acid oxidase on $\epsilon$-acyllysine and lysine. Archives of Biochemistry \& Biophysics 75, 280-289. 